DOI: 10.20472/EFC.2019.012.024

\title{
NOPPAMASH SUVACHART
}

Faculty of Business Administration and Accountancy, Khon Kaen University, Thailand

\section{AN EXPLORATORY STUDY INTO CONSUMERS' PERSPECTIVE FOR ESTABLISHING PRICE STRATEGIES THAT MAINTAINING CONSUMERS' GOOD WILL}

\begin{abstract}
:
This research related to meal price of food truck service business. Descriptive data was collected through a questionnaire survey. Respondents were Thai people age 16 - 35 up years. The vast majority of 226 respondents were in the age group between 21-25 years with 45.2 percent respondents. There were male 35.8 percent and female respondents 64.2 percent. This research indicated the maximum willing to pay was the maximum price at 150 baht. On the other hand, minimum willing to pay was the minimum price at 25 baht. The range of acceptable prices was between 25 - 150 baht. The resulting distribution enabled the researcher to determine upper and lower price limits for western food. The results showed that consumers considered the food to be cheap at 65 baht. If the price fell below 33 baht, the lower limit could cause the item to be judged as being of questionable quality. The consumers considered the highest price at 119 baht. If the price rose over 180 baht, the upper limit can cause the item to be judged as being too expensive, suggesting quality levels and attributes exceeding those desired by the consumers. They felt the food was cheap as felt it was expensive at 50 baht (indifference price). In term of the price stress, the indifference price ( 50 baht) was greater than the optimal price ( 35 baht). They felt some stress over price, since the price that they would most like to pay was lower than the price they view as cheap.
\end{abstract}

\section{Keywords:}

Price sensitivity, Consumer, Pricing

JEL Classification: A10, D00, D49 


\section{Introduction}

Restaurants in Thailand are the top businesses that investors are interested in investing. From database of website Wongnai (1 February 2018) revealed that the restaurant business is growing continuously. There are 205,709 restaurants in Thailand. Number of new restaurants opened in 2017, higher than 2016 accounted for 8.5 percent and higher than in 2015, representing 14.9 percent. Kasikornresearch (Krasairtat, volume 2904, 2018) valuated the restaurant business market in 2018 that's worth 411,000 - 415,000 million baht with growth rate of 4-5 percent from 2017. At present, there are more restaurant operators operating in department stores and large retailers. By expanding the branches of department stores and large retailers and increasing the proportion of $30-40 \%$ to be part of food destination which is open space for restaurant operators, restaurant chains, entrepreneurs and general retail operators. It can be said that it is an increase and more diverse in dining options in department stores and large retailers. From the original, mainly used as a restaurant chain services. However, Increasing the proportion of restaurants in department stores and large retailers, is both a competitive position for department stores and large retailers as a destination for eating (food destination), by using a restaurant as a magnet to attract consumers to use the services of department stores and large retailers, and also allows new restaurant operators to enter the business. This strategy results cause more intense competition between restaurant operators in department stores and large retailers. In addition, rising business costs is a challenge for restaurant operators. The renting space in a high potential location including rising labor costs affects all restaurant operators. The expansion is partly due to the cost push. Especially, rental space in potential locations and labor costs that result in operators having to set at high level food prices in order to cover various costs Increasing. In 2018, the expansion of the restaurant branches is still a strategy that restaurant operators pay attention. Even though the expansion of branches will enhance expanding the total revenue of the restaurant operators but most of them come from the revenue of new branches, because of customers having a tendency to spread the use of new branches. It consequently resulting in lower revenue of the old branches or grow slowly. Therefore, the challenge of entrepreneurs is to determine the position of the competition, select the food service model that attracts customers and the pricing that the customer can accept. Including selection of locations for opening or expanding branches which must be a location that can reach the customer base in order not to affect the revenue of the old branch. By means of expansion of branches to new areas where the competition is not intense including the rental rate is not very high. The food service operators also have the opportunity to expand the branch to new locations with open areas for restaurants such as gas Station, office buildings in the city center area where the target customers are the group with purchasing power including hospitals with various services to facilitate patients and visitors (Kasikornresearch, Krasairtat, volume 2904, 2018).

The rise of the food trucks or mobile culinary services has many chefs jumping into the mobile food industry. At Bangkok the mobile gourmet revolution hits the streets. A food truck is a large vehicle equipped to cook and sell food. Some, including ice cream trucks, sell frozen or prepackaged food; others have on-board kitchens and prepare food from scratch. Sandwiches, hamburgers, French fries, and other regional fast food fare is common. In recent years, associated with the pop-up restaurant phenomenon, food trucks offering gourmet cuisine and a variety of specialties and ethnic menus, have become particularly popular in Thailand. Food trucks are subject to the same range of concerns as other culinary service businesses. They generally require a fixed address to accept delivery of supplies. A commercial kitchen may be needed for food prep. There are a variety of permits to obtain, and a health code to observe. Labor and fuel costs are significant part of the overhead. So pricing is very important. Price must be set to cover expenses under condition of customers' acceptable price range. 


\section{Statement of the problem and justification}

Food truck service owners should considerable steps in establishing price strategies that have improved the bottom line while maintaining consumers' good will. Those prices are also often set without an understanding of customers' perceptions of price. The matter of pricing for food truck services confronts at least three complex factors (Valerie Zeithaml and Mary Jo Bitner, 2012) : (1) customers often have inaccurate of limited reference prices for services, (2) customers use price as a key signal for quality, and (3) monetary prices is not the only relevant cost for service customers. Because of the complexity of pricing services, researcher believes the food truck service owners will find it useful to measure customer's price sensitivity before establishing prices for food items or determining what the price should be. The owners first determine what customers are willing to pay for a food items and then determine what they need to do to develop a product in that price range. If the price customers are willing to pay could not guarantee a profit, then the product was not further developed. This research will explore price sensitivity of customers' food truck services. It will determine a range of acceptable prices and an optimal price point based on an analysis of price ratings obtained from customers. Key data analyzed is from responses to questions about what prices for a food truck service are considered too cheap or too expensive. Plotting this information onto price maps shows cheap/expensive, too cheap/too expensive, price-stress analysis, and range of acceptable price thresholds as well as the price point considered optimal.

\section{Objectives of research}

The objectives of this research are five-fold:

1. To identify cheap price, expensive price for food truck services.

2. To identify too cheap price, too expensive price for food truck services.

3. To identify indifference price, optimum price, and price stress for food truck services.

4. To identify range of acceptable price for food truck services.

5. To measure the price sensitivity of food truck services.

\section{Research Variables}

Dependent variables are customers' price-sensitivity (cheap price, expensive price, indifference price, too expensive price, too cheap price, optimum price, price stress, and range of acceptable price). Independent variables are level of price (open end).

\section{Operational Definition}

1. Customers' price-sensitivity

In consumer behavior, price sensitivity (also called the elasticity of demand) is the degree to which price affects the sales of food at food truck service. Customers' price-sensitivity means the degree to which demand drops as you increase the price of food.

2. Willingness to pay

Willingness to pay (WTP) is the maximum amount an individual is willing to buy food at food truck service. The price of the transaction will thus be at a point somewhere between a buyer's willingness to pay and a seller's willingness to accept. 


\section{Research Conceptual framework}

This research has framed the research concept as follows:

Independent variable

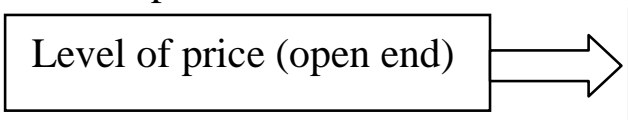

Dependent variable

Customers' price-sensitivity

- Cheap price

- Expensive price

- Indifference price

- Too expensive price

- Too cheap price

- Optimum price

- Price Stress

- Range of acceptable price

Figure 1. Research conceptual framework

\section{Literature review}

\section{Price-Sensitivity measurement}

Price sensitivity was explored by Andre Gabo and Clive Granger that presented in the journal Management decision. Gabor and Granger proceeded a study in which they asked respondents to state the highest and lowest prices at which they would purchase selected inexpensive items. The resulting distribution enabled the researchers to determine upper and lower price limits for these products. Gabor and Granger suggested that within these limits price may continue to act as a quality indicator but does not act as an absolute barrier to purchase. Outward these limits, however, price may act as the dominant indicator of quality and, further, may become a barrier. A price falling above the upper limit can cause the item to be judged as being too expensive, suggesting quality levels and attributes exceeding those desired by the customer. A price falling below the lower limit, on the other hand, can cause the item to be judged as being of questionable quality. The price-sensitivity measurement (PSM) contains four questions. When customers' compile responses to those questions are graphed, the model indicates the price-sensitivity level of the market being tested. The questions are:

1. At what price on the scale do you consider the product or service to be cheap?

2. At what price on the scale do you consider the product or service to be expensive?

3. At what price on the scale do you consider the product or service to be too expensive, so expensive that you would not consider buying?

4. At what price on the scale do you consider the product or service to be too cheap, so cheap that you would question the quality?

The respondents to those questions are analyzed statistically and plotted on a graph. Lewis and Shoemaker (1997) explained in the Cornell Hotel and Restaurant Administration Quarterly that the first two questions are used to determine the indifference price, or the price at which an equal number of respondents feel the service is cheap as feel it is expensive (Graph A). 


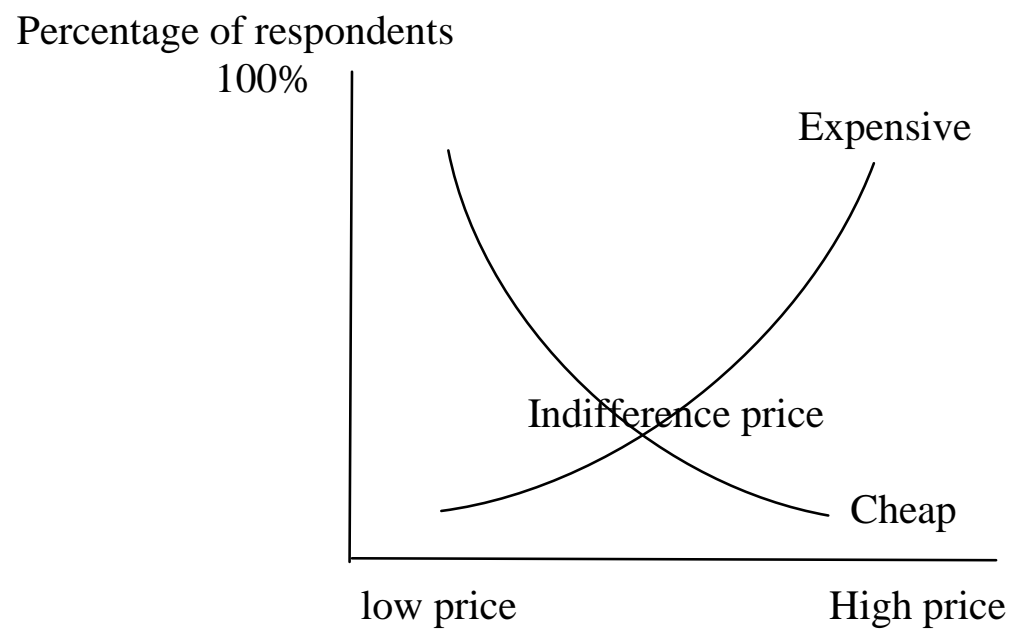

Figure 2. Graph A

The second two questions are used to determine the optimal pricing point, the price at which customer resistance to purchase is at its lowest and an equal number feel the service is too cheap as feel it is too expensive (Graph B).

Percentage of respondents

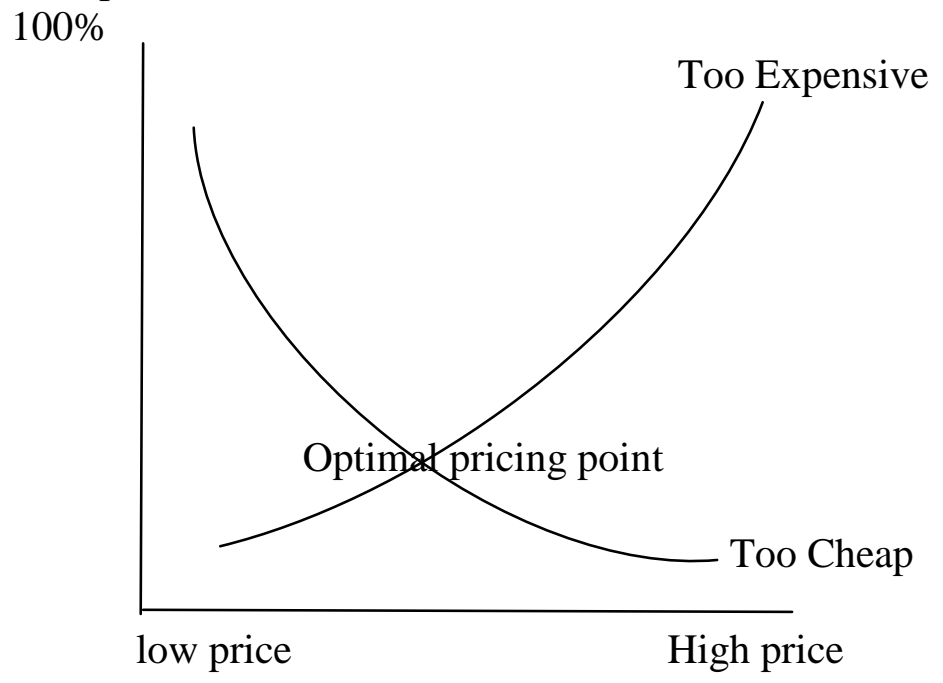

Figure 3 Graph B

When the four cumulative distributions are combined, one can determine whether there is "stress" in price consciousness (Graph C). The closer the optimum price is to indifference price, the less price-conscious are the respondents. The more the optimum price falls to the left of the indifference price, the greater is the number of consumers who feel the "normal" price is too high that is, they are more sensitive to price. 
Percentage of respondents

$100 \%$

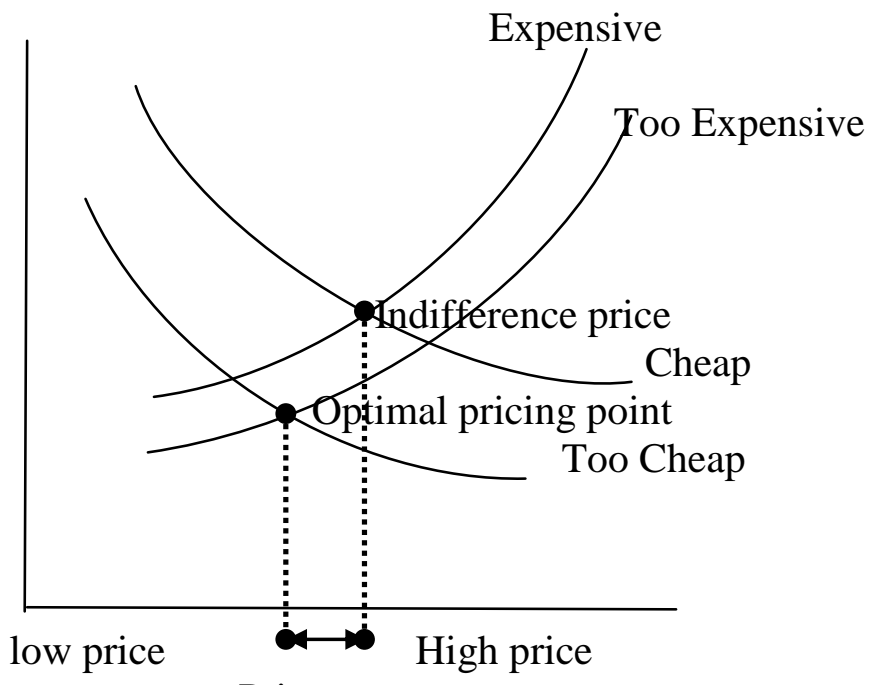

Price stress

Figure 4. Graph C

The final manipulation gives the range of acceptable prices. This results in a four-curves are graphed with the reversed cumulative distributions of the "cheap" and "expensive" curves. Which can then be labeled "not cheap" and "not expensive" (Graph D). The basis for the inversion is that, logically, if something is expensive it is not cheap. But asking respondents to state a price that they consider "not cheap" is awkward and prone to error. The intersection of the two reversed curves is the point of marginal cheapness (PMC), or the point where the number of respondents who feel the service is too cheap is equal to the number of respondents who feel it is not cheap (Graph D)

Percentage of respondents

$100 \%$

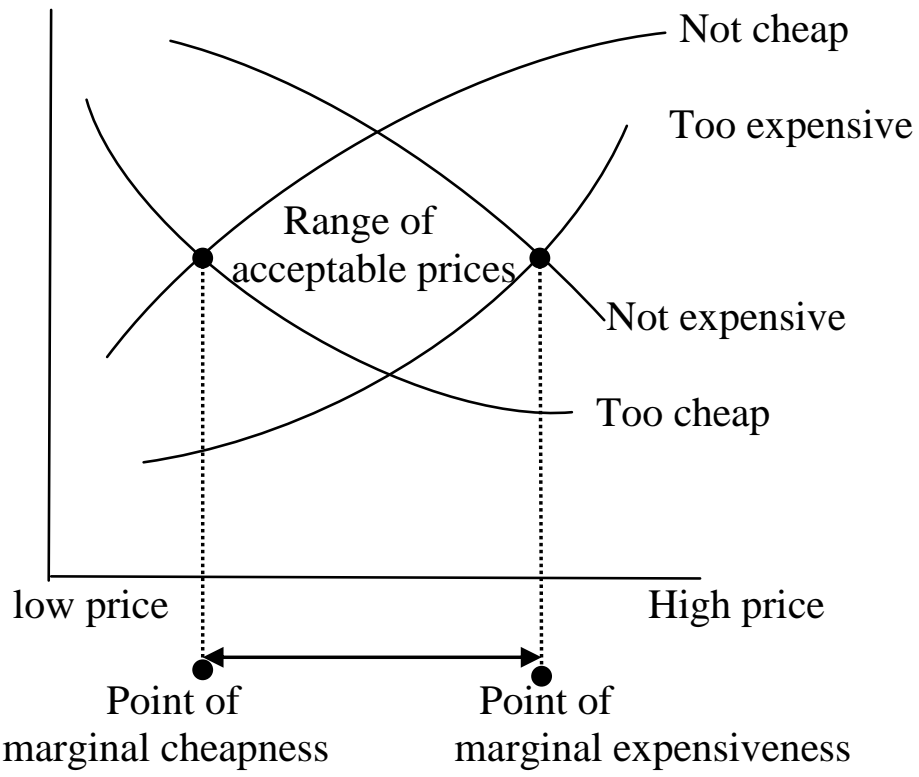

Figure 5. Graph D 
The intersection of the "not expensive" and "too expensive" curves is the point of marginal expensiveness (PME). This is the price point where the number of respondents who feel the service is too expensive is equal to the number of respondents who feel it is not expensive.

The range of acceptable prices has the point of marginal cheapness as its lower price limit and the point of marginal expensiveness as its upper price limit. Operators would be imprudent to price outside this range unless there is real change in the perceived value of positioning of the product or service. (Lewis and Shoemaker, 1997)

\section{Pricing}

Price has a significant role in selecting a product. For company point of view price is reward or value given in return of need fulfilment to company. Perceived customer expectations and price should be in accordance with each other. Skindaras (2009) we can discover a lot of merchandise on this planet possessing different price ranges. Price is one of the four P's of Marketing Mix that has significant role in implementation of marketing strategy. (Kottler \& Armstrong 2012). Han (2009) claim that one of the most adaptable factors which improved quickly is the pricing (Andalleb et al., 2006) the costs associated with restaurant merchandise furthermore vary according to style of restaurant. If your price is large, clients may very well expect premium quality. " Also, in the event the price is minimal, clients may perhaps believe that restaurant is poor in terms of merchandise and also program excellent. Furthermore, because of the competition within of the restaurant industry, clients will be able to identify interior reference point price ranges inside their head plus they constantly evaluate and also analyze the values in terms of many characteristics associated with restaurant upon every acquire, an inside reference point price is understood to be an expense within potential buyers 'memory of which acts as a criteria intended for contrasting precise price ranges (Grewal et al., 1998). Besides previously mentioned variables preference associated with merchandise, campaign, within aspect actual physical environment and also program excellent also have major romantic relationship toward customer satisfaction within fast food industry associated with chosen human population. Andleeb (2006) researched of which price or cost associated with restaurant furthermore varies as outlined by style of restaurant. Shoppers may very well understand price associated with restaurant in terms of its merchandise and also program excellent. In accordance with Chang \& Wildt (1998) the value provides its major influence upon customer perception about quality if it's really the only details indicated available. In respect the study associated with buyer want to undertake a price and also quality instead of complex elements within sturdy items (Chui et al., 2006).

\section{Willingness to pay (WTP)}

The maximum WTP is the maximum price at which a consumer would buy a unit of a product or service (Wang, et al., 2007). The WTP of an individual or a household can generally be estimated based on panel data or data generated from surveys or experiments. Direct questioning is one of several common elicitation methods for WTP (Jedidi and Jagpal. 2009). Miller et al. (2011) revealed that hypothetical methods also lead to correct demand curves and pricing decisions. Furthermore, they showed that a direct elicitation approach is more suitable for relatively lowerpriced, more frequently purchased, non-durable products (Miller et al., 2011) as food product are.

\section{Development measuring instrument and scale measurement Instrument}

The instrument was based on price-sensitivity measurement (PSM) developed by Lewis and Shoemaker (1997). To generate the range of prices, respondents were first saw burgers as illustrations for queries. 


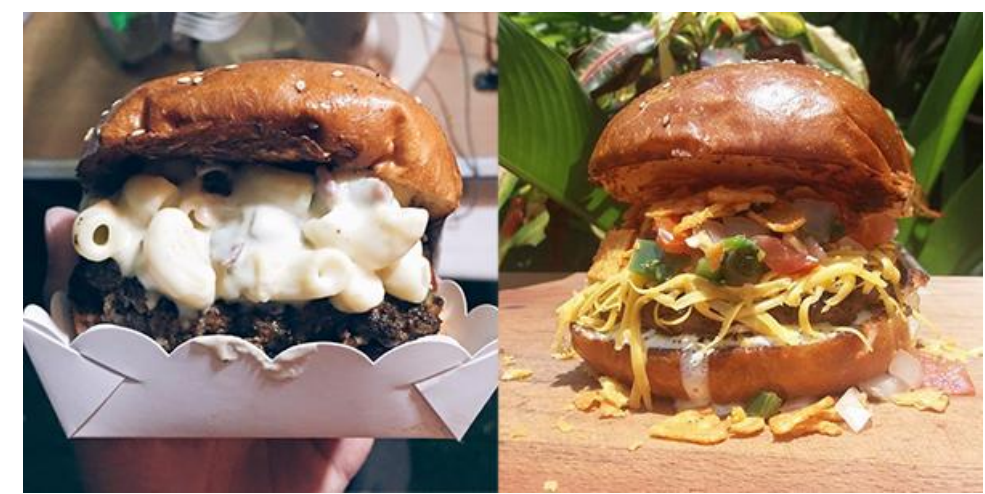

They are then asked the following six questions:

1. What is your gender? Male / Female

2 How old are you? years (Open-Ended question)

3. Assuming you could buy this food at food truck, at what price would consider this item to be cheap? baht (Open-Ended question)

4. Assuming you could buy this food at food truck, at what price would consider this item to be expensive? baht (Open-Ended question)

5. Assuming you could buy this food at food truck, at what price would this item be so expensive that you would not purchase the product? baht (Open-Ended question)

6. Assuming you could buy this food at food truck, at what price would this item be so cheap that you would worry about the quality? baht (Open-Ended question)

\section{Description of Procedures}

This research involved collecting data in order to answer questions concerning the meal price of food truck service. Descriptive data were collected through a questionnaire survey. Customers' perspectives were measured through a page self-completed questionnaire written in Thai, administered to a sample of 500 respondents of the district in Bangkok, Thailand. Respondents' questionnaires were distributed within 4 months. The questionnaire comprised 6 questions. The first part contained basic data of respondents' gender and age with 4 open ended questions aimed to identify the range of prices being staged. Once collected, all data were entered into SPSS version 15.0 for further analysis. Descriptive statistics are used to describe the subjects and customers' price-sensitivity. The results information presented by descriptive with percentage $(\%)$ and mean in the form of tables, graph, and text.

\section{Respondents' demographic profiles}

Respondents of this research are Thai people age 16 - 35 up years who living in Bangkok. Since the population has 67,931 members, researcher is concerned with 500 subjects. A total of 500 questionnaires are distributed between October 2017-January 2018. The socio-demographic profiles of respondents almost 64.2 percent are female and 35.8 percent are male. Concerning the age of the respondents, the majority of them (45.2 percent) are between 21-25 years old. The corresponding numbers of respondents aged 16-20, 21-25, 26-30, 31-35, and 35 or above were $65(13 \%), 226$ (45.2\%), 68 (13.6\%), 49 (9.8\%), $92(18.4 \%)$, respectively (Table 1). 
Table 1. Respondents' demographic profiles $(\mathrm{N}=500)$

\begin{tabular}{cll}
\hline & Frequency & Percentage \\
\hline $\begin{array}{c}\text { Gender } \\
\text { female } \\
\text { male }\end{array}$ & 321 & 64.2 \\
$\begin{array}{c}\text { Age } \\
16-20\end{array}$ & 179 & 35.8 \\
$21-25$ & 65 & \\
$26-30$ & 226 & 43.0 \\
$31-35$ & 68 & 13.6 \\
35 up & 49 & 9.8 \\
& 92 & 18.4
\end{tabular}

\section{Major Findings}

1. The customers considered the product or service to be cheap at 65 baht.

2. The customers considered the product or service to be expensive at 119 baht.

3. In term of the indifference price, the researcher found the price at which an equal number of respondents feel the service was cheap as feel it is expensive was 50 baht.

4. They felt it was too expensive to purchase or too expensive at $180 \mathrm{baht}$.

5. They felt it was too cheap to purchase or too cheap at 33 baht.

6. In term of the optimum price, the price at which an equal number of respondents felt the service was too cheap as feel it was too expensive is 35 baht.

7. In term of the price stress, the indifference price $(50$ baht) is greater than the optimal price (35 baht). They felt some stress over price, since the price that they would most like to pay is lower than the price they view as cheap.

8. The range of acceptable prices was between $25-150$ baht.

\section{Research Limitations}

Research limitations related to the following points:

1. Cuisine type, this research was suitable for Western cuisines such as burgers because researcher used burgers as illustrations for queries.

2. Population scope, this research was representative of people in Bangkok, Thailand.

\section{Conclusions and discussion}

From marketing standpoint, businesses should set prices at the exact best point at which seller and buyer produce the optimum revenue. This is known as equilibrium price. In reality, it is very difficult to achieve the perfect price, even though computer software models and real-time analysis of sales volume at given price points has helped in this area. Even if a slight price increase diminishes sales volume, the relative gains in revenue on each product may overcome a proportionally smaller decline in customer purchases. Therefore, setting the right price is important for the business.

This research indicated the maximum willing to pay was the maximum price at $150 \mathrm{baht}$. On the other hand, minimum willing to pay was the minimum price at 25 baht. The range of acceptable prices was between 25 - 150 baht. We asked respondents to state the highest and lowest prices of food at food truck services. The resulting distribution enabled the researchers to determine upper and lower price limits for western food (burger). The results showed that customers consider the 
food to be cheap at 65 baht. If the price fell below 33 baht, the lower limit could cause the item to be judged as being of questionable quality. The customers consider the highest price at $119 \mathrm{baht}$. If the price rose over 180 baht, the upper limit can cause the item to be judged as being too expensive, suggesting quality levels and attributes exceeding those desired by the customers. They felt the food was cheap as felt it was expensive at 50 baht (indifference price). Gabor and Granger suggested that within these limits price may continue to act as a quality indicator but does not act as an absolute barrier to purchase. Outward these limits, however, price may act as the dominant indicator of quality and, further, may become a barrier. Buyers will be more willing to pay if they believe that a higher price signals higher quality. A price rising above the upper limit can cause the item to be judged as being too expensive, suggesting quality levels and attributes exceeding those desired by the customer. A price falling below the lower limit, on the other hand, can cause the item to be judged as being of questionable quality. In term of the optimum price, the price at which an equal number of respondents felt the service was too cheap as felt it was too expensive was 35 baht. In term of the price stress, the indifference price (50 baht) was greater than the optimal price (35 baht). They felt some stress over price, since the price that they would most like to pay was lower than the price they view as cheap. If the owners understood customer willingness-to-pay before any negotiations commenced, they could develop strategies to realize that price during the negotiation. Salespeople rely on their experience and selling skills to draw out this information using historical data and value-based pricing methodologies to understand how a customer values their products.

Influences on Price-Sensitivity

Several common factors affect the level of sensitivity customers generally have within a particular industry or toward a certain product. Buyers of luxury goods are often less sensitive than buyers of everyday products. The more options a buyer has, the more sensitive he is to a price change in most cases. Higher-priced products, such as cars, luxury hotel and popular luxury brands goods, usually lead to greater price sensitivity since they take up a large percentage of the buyer's budget.

\section{Pricing Strategy}

The Reputation of shop, chef or branding and pricing strategies contribute to the level of price sensitivity in the market. The food truck services typically use advertising and other promotional techniques to make customers less price-focused and more concerned with core product benefits. The more a customer values other benefits, the less price sensitive they becomes. Additionally, establishing and maintaining a higher-end upfront price point is a common approach to making customers less price-conscious. Targeting higher-income buyers is another strategy. Some food truck services use penetration pricing, or low upfront prices to attract customers, often at the risk of establishing price-orientation and sensitivity at the onset of a product launch.

The findings of research determined that the order of importance of the following tools for marketing food truck services were as follows: good three locations are shopping and parking area, festivals and food truck events and night life sites, respectively. The results revealed the marketing strategy elements of food truck service were safe and tasty food, good value for money, and reputational resonance, were being used under heading of responsiveness to check the service quality that was contributing maximum towards customer satisfaction in food truck service industry. This showed the importance of a diverse array of communication and marketing to customers to influence their selection of food truck services. 


\section{Future researches}

The future research assumption to be studied is food truck services demand estimation or buying intentions survey and food truck services market segmentation.

Second assumption to be studied is investigating price knowledge, willingness to pay and real purchase decision in order to gain insights into food truck services customers' price sensitivity.

Third assumption to be studied is exploring the relationship between cuisine types and culinary services pricing/meal price. For example, Thai cuisine compares to Korean, Japanese, Chinese, and Vietnamese cuisines.

\section{Acknowledgments}

Grateful acknowledgement is here made to Faculty of Business Administration and Accountancy, Khon Kaen University. This work would not have reached its present form without their supports.

\section{References}

Andaleeb, S. S., \& Conway, C. (2006). Customer satisfaction in the restaurant industry: an examination of the transaction-specific model. Journal of Services Marketing, 20(1), 3-11.

Andre Gabor, Clive W.J. Granger. (1979). Price as an indicator of quality: Report on an Enquiry. Management Decision. Vol.17. issue 8. pp. 590-618.

Bahri-Ammari, N., Van Niekerk, M., Khelil, H.B. and Chtioui, J. (2016), "The effects of brand attachment on behavioral loyalty in the luxury restaurant sector", International Journal of Contemporary Hospitality Management, Vol. 28 No. 3, pp. 559-585.

Barrows, C. and Vieira, E., Jr. (2013), "Recommendations for the development of a new operational classification system for the foodservice industry", Journal of Hospitality \& Tourism Research, Vol. 37 No. 3, pp. 349-376.

Bright, S.N., Kwon, J., Bednar, C. and Newcomer, J. (2009), "Institutional foodservice benchmarking: survey of administrators' attitudes and practices in the USA", Journal of Foodservice, Vol. 20, pp. 123-132.

Canziani, B., Almanza, B., Frash, R.E., Jr., McKeig, M. and Sullivan-Reid, C. (2016), "Classifying restaurants to improve usability of restaurant research", International Journal of Contemporary Hospitality Management, Vol. 28 No. 7, accessed at: www.emeraldinsight.com/doi/pdfplus/10. 1108/IJCHM-12-2014-0618

Chang, Z. \& Wildt, R. (1998). Impact of product information on the use of price as a quality cue. Psychology \& Marketing, 13(1), 55-75.

Chiu, J., Chen, H., Tzeng, G., \& Shyu, J., (2006). Marketing strategy based on customer behavior for the LCD-TV. Int. J. Management and Decision Making, 7(2/30), 143-165.

DiPietro, R.B. and Milman, A. (2008), "Retention factors of tipped hourly employees in the casual dining restaurant segment: exploratory research in Central Florida", International Journal of Hospitality \& Tourism Administration, Vol. 9 No. 3, pp. 244-266. 
DiPietro, R.B. and Partlow, C. (2014), "Customer expectations of casual dining restaurants: the case of Liberty Tap Room", International Journal of Hospitality and Tourism Administration, Vol. 15 No. 4, pp. 376-393.

Dziadkowiec, J. and Rood, A.S. (2015), "Casual dining restaurant preferences: a cross-cultural comparison”, Journal of Foodservice Business Research, Vol. 18 No. 1, pp. 73-91.

Grewal, D. Monroe, K. B., \& Krishnan, R. (1998). The effects of price comparison advertising on buyers' perceptions of acquisitions value, transaction value, and behavioural intentions. Journal of Marketing, 62(2), 46-59.

Ha, J. and Jang, S. (Shawn) (2010), "Effects of service quality and food quality: the moderating role of atmospherics in an ethnic restaurant segment", International Journal of Hospitality Management, Vol. 29 No. 3, pp. 520-529.

Ha, J. and Jang, S.S. (2012), "Consumer dining value: does it vary across different restaurant segments?”, Journal of Foodservice Business Research, Vol. 15 No. 2, pp. 123-142.

Ha, J. and Jang, S.S. (2013), “Attributes, consequences, and consumer values: a means-end chain approach across restaurant segments", International Journal of Contemporary Hospitality Management, Vol. 25 No. 3, pp. 383-409.

Han, H. and Ryu, K. (2009), "The roles of the physical environment, price perception, and customer satisfaction in determining customer loyalty in the restaurant industry", Journal of Hospitality \& Tourism Research, Vol. 33 No. 4, pp. 487-510.

Han, H., \& Rye, K. (2009). The roles of the physical environment, price perception, and customer satisfaction in determining customer loyalty in the restaurant industry. Journal of Hospitality \& Tourism Research. 33(4), 487-510.

Harrington, R.J., Fauser, S.G., Ottenbacher, M.C. and Kruse, A. (2013), “Key information sources impacting Michelin restaurant choice", Journal of Foodservice Business Research, Vol. 16, pp. 219-234.

Hu, H.H., Parsa, H.G. and Zhao, J.L. (2006), "The magic of price-ending choices in European restaurants: a comparative study", International Journal of Contemporary Hospitality Management, Vol. 18 Nos 2/3, pp. 110-122.

Jang, S. (Shawn), Ha, J. and Park, K. (2012), "Effects of ethnic authenticity: investigating Korean restaurant customers in the US", International Journal of Hospitality Management, Vol. 31 No. 3, pp. 990-1003.

Jedidi, K. and Jagpal, S. (2009). Willingness to pay: measurement and managerial implications. Handbook of Pricing Research in Marketing. Edward Elgar, Cheltenham, Northampton. pp. 37-60.

Kasikorn Research Center. (2018). Culinary services business trend analysis. Retrieved February 1, 2018, from https://kasikornresearch.com/th/analysis/k-econ/business/Pages/36839.aspx

Kimes, S.E. (2008), "The role of technology in restaurant revenue management", Cornell Hospitality Quarterly, Vol. 49 No. 3, pp. 297-309. Kimes, S.E. and Wirtz, J. (2002), "Perceived fairness of demand-based pricing for restaurants", Cornell Hotel and Restaurant Administration Quarterly, Vol. 43 No. 1, pp. 31-37. 
Kimes, S.E., Chase, R.B., Choi, S., Lee, P.Y. and Ngonzi, E.N. (1998), "Restaurant revenue management: applying yield management to the restaurant industry", Cornell Hotel and Restaurant Administration Quarterly, Vol. 39, pp. 32-39.

Kivela, J.J. (1997), "Restaurant marketing: Selection and segmentation in Hong Kong", International Journal of Contemporary Hospitality Management, Vol. 9 No. 3, pp. 116123.

Kotler, P. \& Armstrong, G. (2012). Principles of Marketing 14th ed, New Jersey: Prentice Hall.

Lee, K. and Ha, I.S. (2012), "Exploring the impacts of key economic indicators and economic recessions in the restaurant industry", Journal of Hospitality Marketing \& Management, Vol. 21 No. 3, pp. 330-343.

Mac Con Iomaire, M. (2013), "Public dining in Dublin: the history and evolution of gastronomy and commercial dining 1700-1900", International Journal of Contemporary Hospitality Management, Vol. 25 No. 2, pp. 227-246.

Madanoglu, M., Erdem, M. and Gursoy, D. (2008), "Risk return and cost of equity of small and large casual-dining restaurants", International Journal of Hospitality Management, Vol. 27 No. 1, pp. 109-118.

Madanoglu, M., Lee, K. and Kwansa, F.A. (2008), "Risk-return analysis of fast-food versus casualdining restaurants: who moved my cheeseburger?”, Journal of Hospitality \& Tourism Research, Vol. 32 No. 3, pp. 327-341.

Miller, Klaus M., Hofstetter R., Krohmer, H., and Zhang, Z.J. (2011). How should consumers' willingness to pay be measured? An empirical comparison of the state-of-the-art approaches. Journal of Marketing Research, Vol. 48. Issue 1. pp.172-184.

Muller, C.C. and Woods, R.H. (1994), “An expanded restaurant typology”, The Cornell Hotel and Restaurant Administration Quarterly, Vol. 35 No. 3, pp. 27-37.

Murphy, K.S. and Olsen, M. (2009), "Dimensions of high performance management system: an exploratory study of the US casual restaurant segment", International Journal of Contemporary Hospitality Management, Vol. 21 Nos 6/7, pp. 836-853.

Murphy, K.S., DiPietro, R.B., Rivera, M. and Muller, C.C. (2009), “An exploratory case study of factors that impact the turnover intentions and job satisfaction of multi-unit managers in the casual IJCHM 29,4 1230 theme segment of the US restaurant industry", Journal of Foodservice Business Research, Vol. 12 No. 3, pp. 200-218.

Naipaul, S. and Parsa, H.G. (2001), "Menu price endings that communicate value and quality", Cornell Hotel and Restaurant Administration Quarterly, Vol. 42 No. 1, pp. 26-37.

Ogaard, T., Larsen, S. and Marnburg, E. (2005), "Organizational culture and performanceevidence from the fast food restaurant industry", Food Service Technology, Vol. 5 No. 1, pp. 23-34.

Ottenbacher, M.C. and Harrington, R.J. (2009), "The product innovation process of quick-service restaurant chains", International Journal of Contemporary Hospitality Management, Vol. 21 No. 5, pp. 523-541. 
Peng, C., Bilgihan, A. and Kandampully, J. (2015), "How do diners make decisions among casual dining restaurants? An exploratory study of college students", International Journal of Hospitality \& Tourism Administration, Vol. 16 No. 1, pp. 1-15.

Rattana SaiKanit, 2008, Economic for Management, The Textbook Project number 13, Economic Faculty, Bangkok; Chulalongkorn University

Robert C. Lewis and Stowe Shoemaker. (1997). Price-sensitivity measurement: A tool for the hospitality industry. Cornell Hotel and Restaurant Administration Quarterly. Vol. 38. Issue 2. pp. 44-54.

Ryu, K. and Han, H. (2010), "Influence of the quality of food, service, and physical environment on customer satisfaction and behavioral intention in quick-casual restaurants: moderating role of perceived price", Journal of Hospitality \& Tourism Research, Vol. 34 No. 3, pp. 310329.

Ryu, K. and Jang, S.S. (2008), "Influence of restaurants' physical environments on emotion and behavioral intention", The Service Industries Journal, Vol. 28 No. 8, pp. 1151-1165.

Siljaru, T. 2005, Research and Statistic Data Analysis by SPSS version 10-13, Business R and D Ordinary Partnership, Bangkok.

Skindaras, R. V. V. S. D. (2009). The relationship between Price and Loyalty in Services Industry, ISSN 1392 - 2785 Inzinerine EkonomikaEngineering Economics Commerce of engineering decisions, p. 3.

Valerie Zeithaml and Mary Jo Bitner, 2012. Services Marketing. $6^{\text {th }}$ edition. New York: McGraw Hill. p.484.

Wang, T., Venkatesh, R. and Chatterjee, R. (2007). Reservation price as a range: an incentive compatible measurement approach. Journal of Marketing Research, Vol. 44. No. 2. Pp.200-213.

Weiss, R., Feinstein, A.H. and Dalbor, M. (2004), "Customer satisfaction of theme restaurant attributes and their influence on return intent", Journal of Foodservice Business Research, Vol. 7 No. 1, pp. 23-41.

Wongnai Media Co., Ltd. (2018). Summary of restaurant information and trends in Thailand 2018. Retrieved February 1, 2018, from https://www.wongnai.com/business-owners/thailandrestaurant-trend-2018.

Yang, C.Y. and Chang, T.Y. (2011), "Binomial real option pricing for restaurant menu analysis", Cornell Hospitality Quarterly, Vol. 52 No. 3, pp. 273-282.

Zheng, T., Farrish, J. and Wang, X. (2012), "How did different restaurant segments perform differently through the recession? An ARIMA with intervention analysis on US restaurant stock indices", Journal of Hospitality Financial Management, Vol. 20 No. 2, pp. 1-25. 